\section{The terrier's way}

Ryuichi Inoue and Alun Anderson

Imanishi Shinkaron Hihan no Tabi.* By Beverly Halstead. Translated by Akiko Nakayama and Suisen Sakuramachi. Tsukiji Shokan, Tsukiji 2-10-12, Chuo-ku, Tokyo 104, Japan:1988. Pp.282. Pbk $¥ 2,200$.

Beverly Halstead, Reader in the Departments of Geology and Zoology at the University of Reading in Britain, was once described by a colleague as "Darwin's terrier". Terriers are small dogs, once used to hunt rats. Nevertheless, Halstead says that the description appeals to him. He admires the terrier's sharp teeth and its unwillingness to let go. Like T.H. Huxley, "Darwin"s bulldog" in the nineteenth century, Halstead has been vigorous in his defence of mainstream evolutionary theory. Most memorable was his attack on the cladists in 1980, which triggered a debate that occupied the correspondence columns of Nature for a year.

In his new book, Halstead tells how he scented anti-Darwinism while on a short visit to Kyoto University in 1984. Ostensibly, the book is an account of his pursuit of the theories of Kinji Imanishi, Emeritus Professor of Zoology at Kyoto University, now over 80 years old and a prolific author of great reputation in Japan. But the book is an unusual one; it is published only in Japanese and it fits into no simple category. It is part travelogue, part science text, part personal diary and part exposé.

With little time in Japan, Halstead attacked his subject with manic energy. It mattered little that all of Imanishi's works are in Japanese; he persuaded students to paraphrase them into English. It mattered less that many of the people he wished to interrogate could not speak English; he press-ganged anyone he could find into taking on day-long interpreting sessions

Halstead's intellectual progress provides the best part of the book. He reveals not just his conclusions - an account of Imanishi's theory and its faults (see Nature 317, 587; 1985) - but also his ways of digging and delving, his blunders and his successes.

Finally, Halstead met Imanishi. They agreed about almost nothing, but Imanishi gave him his seal of approval. Halstead, it seems, had understood his ideas. Halstead, however, wished to go further. He wanted to understand the whole Imanishi phenomenon; why it is that an evolutionary theory which appears to defy common sense by denying both intra- and inter-specific competition has become popular in Japan. He looked for *Imanishi's Theory of Evolution: A Critical Journey. answers in Japanese society, and for the Japanese reader the story of his search will be a delight. Each new experience sent the terrier off in a wholly unexpected new direction; he met the great and the eccentric in Japan's geological community and discovered phenomena - such as the Chidanken's 'democratic geology' and mass excavations - that few foreigners ever see. On this journey he dug decp into people's backgrounds, and in the book he speculates fiercely about Japan and his Japanese friends

To understand how this seems to a Japanese, the Western reader might imagine the translated account of a Japanese professor, who speaks no English, who has spent a few months at Oxford and who gradually works out, through the characters he meets, Oxford's contradictions and Britain's hidden class structure.

Ultimately, however, Halstead falls into a trap. He defies the old maxim that "to write a book about Japan you must stay three weeks or thirty years". He stayed a little too long, and in the book he passes from fresh first impressions to oversimplistic theories about the nature of Japan. His final view, that Imanishi's theory has been popular because it offers a dream world of harmony as an antidote to the cruel reality of modern Japan, is naive.

Even though Halstead may be wrong on this count, it matters but little. The path that led him to that view is frankly charted

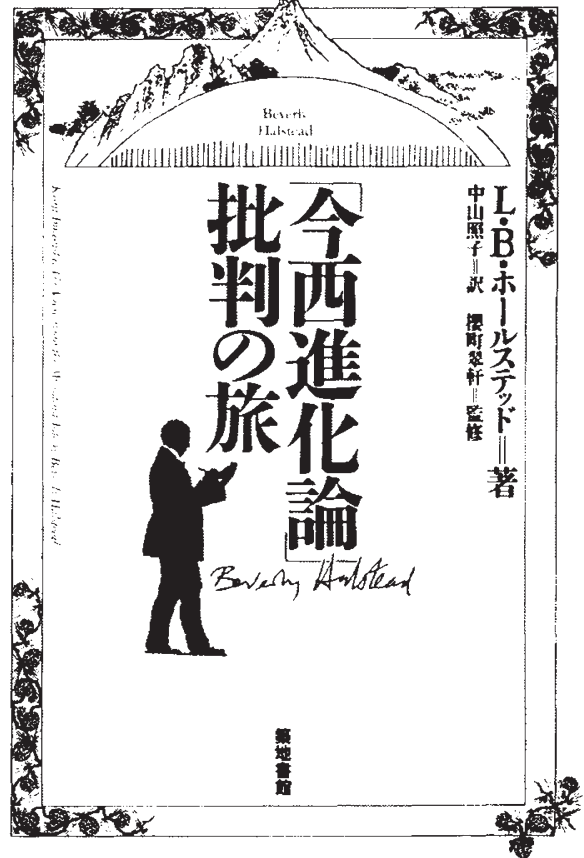

and his mistakes are honest ones. More than for its attack on the Imanishi phenomenon, the book will be admired in Japan for a very un-Japanese quality: its brave refusal to compromise. The terrier's message is that everything can be questioned, and his way of action is on open display.

Ryuichi Inoue, now retired, was formerly a biology teacher in Kanazawa, Japan. Alun Anderson is Washington editor of Nature.

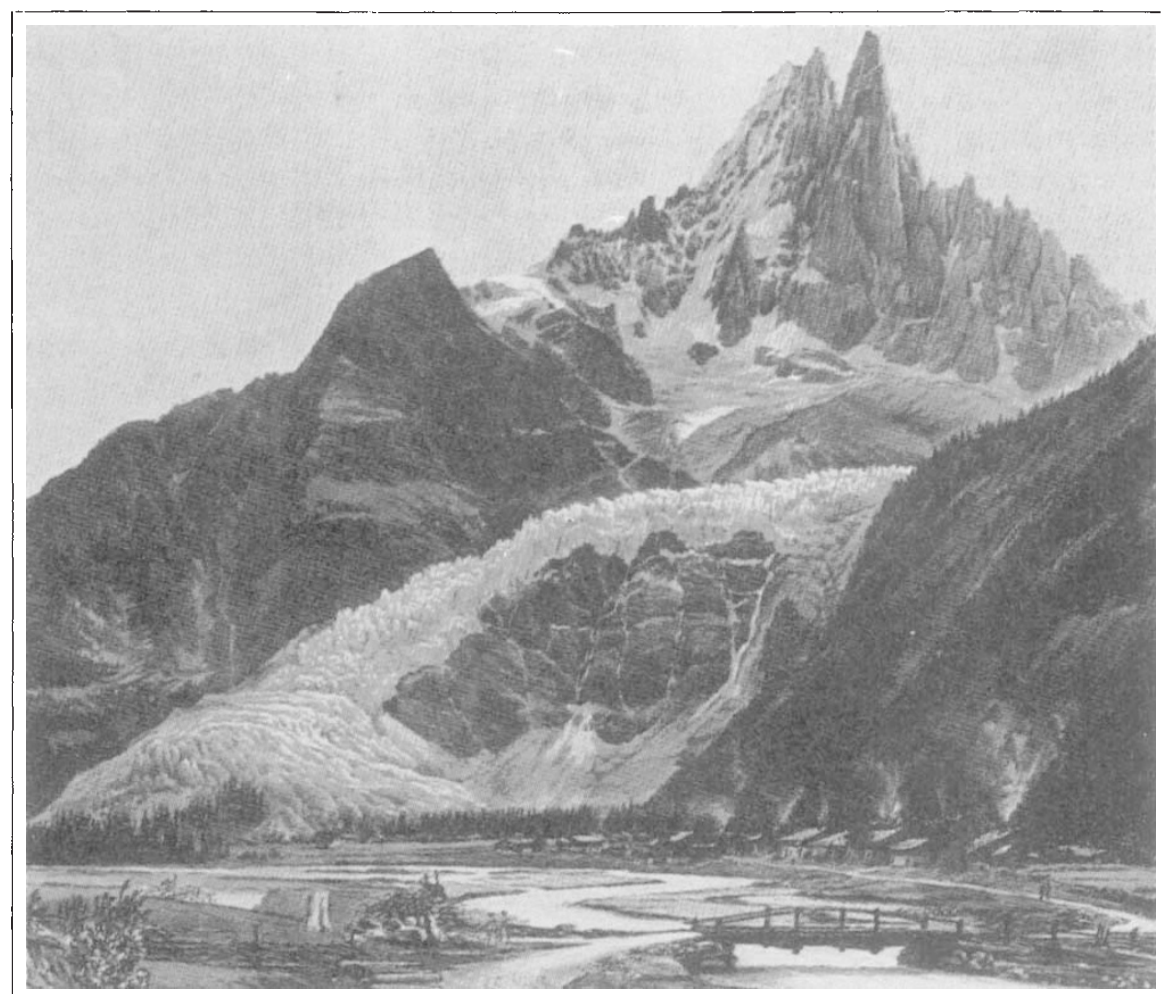

Coming down the mountain --in 1820 the Glacier des Bois, the tongue of the Mer de Glace in the Alps, "attained a distance of only 65 yards from the house of John Marie Tournier, the nearest in the village, where its further progress was providentially stayed" (J.D. Forbes). This 1823 painting of the glacier is taken from The Little Ice Age by Jean M. Grove, to be published next week by Methuen, price $£ 85$. 